\title{
PENGARUH KELEKATAN REMAJA DENGAN IBU, AYAH, DAN TEMAN SEBAYA TERHADAP KENAKALAN REMAJA DI LEMBAGA PEMBINAAN KHUSUS ANAK (LPKA) KELAS II BANDUNG
}

\author{
Wihelmina Fitriani ${ }^{*}$, Dwi Hastuti \\ Departemen IImu Keluarga dan Konsumen, Fakultas Ekologi Manusia, Institut Pertanian Bogor, Bogor 16680,
} Indonesia

*)Email: wihelmina.official@gmail.com

\begin{abstract}
Abstrak
Perilaku kenakalan remaja yang menyebabkan remaja harus menjadi narapidana memerlukan penelaahan lebih lanjut mengenai faktor-faktor penyebabnya sehingga dapat dikembangkan program pencegahan yang lebih tepat sasaran. Penelitian ini bertujuan untuk menganalisis pengaruh kelekatan remaja dengan ibu, ayah, dan teman sebaya terhadap kenakalan remaja yang menjadi anak didik lapas (andikpas) di Lembaga Pembinaan Khusus Anak Kelas II Bandung. Populasi dalam penelitian ini adalah 157 narapidana remaja dengan usia 15-18 tahun. Contoh terdiri dari 63 andikpas yang dipilih menggunakan teknik simple random sampling. Pengambilan data dilakukan dengan teknik wawancara dengan bantuan kuesioner Inventory of Parent and Peer Attachment (IPPA) versi revisi untuk mengukur kelekatan remaja dengan ayah, ibu, dan teman sebaya. Kenakalan remaja diukur dengan menggunakan Adapted Self Report Delinquency Scale (ASRDS). Hasil penelitian menunjukkan proporsi tertinggi kelekatan remaja dengan ibu, ayah, dan teman sebaya berada pada kategori kelekatan tidak aman. Hasil analisis regresi menemukan bahwa kelekatan remaja dengan ayah berpengaruh signifikan negatif terhadap kenakalan remaja. Hal ini menunjukkan bahwa kelekatan remaja yang tidak aman dengan ayah akan meningkatkan perilaku nakal pada remaja. Hasil lainnya menunjukan bahwa kelekatan dengan teman sebaya berpengaruh signifikan positif terhadap kenakalan remaja. Temuan ini mengindikasikan adanya lingkungan pertemanan yang beresiko terhadap kenakalan remaja yang menjadi andikpas di LPKA Kelas II Bandung.
\end{abstract}

Kata kunci: kelekatan remaja-ayah, kelekatan remaja-ibu, kelekatan remaja-teman sebaya, kenakalan remaja

\section{The Influence of Mother-Adolescent, Father-Adolescent, and Peer Group-Adolescent Attachments on Adolescent Delinquency in Lembaga Pembinaan Khusus Anak (LPKA) Kelas II Bandung}

\begin{abstract}
Adolescents delinquency that leads to criminal conduct had to be reviewed to identify the factor that causes it. This study aimed to analyze the influence of mother-adolescent, father-adolescent, and peer group-adolescent attachments on adolescent delinquency in Lembaga Pembinaan Khusus Anak (LPKA) Kelas II Bandung. The population were 157 adolescents known as andikpas (Anak Didik Lapas) with age range from15-18 years old. Participants of the study were 63 andikpas who had been randomly selected from LPKA Kelas II Bandung. Data were collected using interview technique with the questionnaire as the tools. Inventory of Parent and Peer Attachment (IPPA), and the Adapted Self Report Delinquency Scale (ASRDS) were used in the study. The result showed that adolescent had insecure attachment with mother, father, and peer group. Regression analysis showed that father-adolescent attachment had negative effect on adolescent delinquency. This showed that insecure attachment with father increased adolescent's delinquent behaviors. The result also showed that peer group-adolescent attachment had positive effect on adolescent delinquency. This showed that peer group increased the risk for adolescent to conduct delinquent behavior that leads to criminal conduct.
\end{abstract}

Keywords: father-adolescent attachment, mother-adolescent attachment, peer group-adolescent attachment, adolescent delinquency

\section{PENDAHULUAN}

Kenakalan remaja termasuk perilaku melanggar norma yang dilakukan oleh seseorang yang belum dewasa atau berusia di bawah 18 tahun (Cobb, 2001). Menurut Santrock (2003), stigma kenakalan remaja diberikan kepada remaja yang melanggar hukum. Perilaku ini dimulai dari perilaku negatif yang ringan, seperti melanggar peraturan sekolah, tidak masuk sekolah, bolos sekolah, merokok, dan merusak, bahkan sampai perilaku negatif yang berat seperti mencuri, merampok, menyalahgunakan zat kimia, 
memperkosa, dan memiliki senjata (Choon et al., 2013). Oleh karena itu, kenakalan remaja dapat diartikan sebagai perilaku melanggar norma dan hukum yang dilakukan oleh remaja dengan gejala rendah sampai gejala berat bahkan melanggar hukum sehingga dapat dijatuhi hukuman oleh negara.

Berdasarkan data Kementerian Pemuda dan Olahraga (2009), selama tahun 2008 kenakalan remaja termasuk ke dalam tujuh belas Peristiwa Penting Gangguan Kamtibmas (PPGK) khusus. Pada tahun 2008, jumlah anak-anak dan remaja pelaku tindak kriminalitas sebanyak 3.280 orang. Hal ini meningkat sebesar 4,3 persen dari tahun 2007 yaitu sebesar 3.145 orang. Pada tahun 2014, jumlah penyalahgunaan narkoba pun meningkat sekitar 3,8 juta sampai 4,1 juta orang dengan salah satu kategorinya adalah remaja/pelajar (BNN, 2014). Data tersebut menunjukkan adanya peningkatan jumlah remaja yang terlibat dalam perilaku menyimpang bahkan mengarah pada tindakan kriminal.

Remaja yang melakukan tindakan kenakalan dan layak mendapatkan hukuman dimasukkan ke dalam Lembaga Pembinaan Khusus Anak (LPKA) yang saat ini baru ada sebanyak 20 LPKA di seluruh Indonesia (Ditjenpas, 2015a). Berdasarkan laporan Unit Pelaksana Teknis (UPT) Sistem Database Pemasyarakatan (SDP) yang dilakukan Direktorat Jenderal Pemasyarakatan (Ditjen PAS), Kementerian Hukum dan HAM, jumlah andikpas yang terdapat di Lembaga Pembinaan Khusus Anak Kelas II Bandung mengalami peningkatan pada tahun 2015. Pada tahun 2014, terdapat sebanyak 46 andikpas, kemudian terjadi peningkatan yang signifikan pada tahun 2015 yaitu sebanyak 155 andikpas (Ditjenpas, 2015b). Data tersebut menunjukkan bahwa kenakalan remaja di Indonesia, khususnya di wilayah Bandung dan sekitarnya, telah menjadi masalah yang serius dan akan terus meningkat apabila tidak dilakukan tindakan.

Masalah kenakalan remaja yang semakin meningkat perlu diketahui berbagai faktor penyebabnya. Salah satu faktor utama yang menjadi penyebab meningkatnya kenakalan remaja adalah kelekatan remaja dengan orang tua (Hoeve et al., 2012). Kelekatan berkaitan dengan kedekatan emosional antara anak dengan orang tua yang akan menciptakan rasa aman dan membentuk dasar yang kuat bagi kesehatan mental yang positif (Hastuti, 2015). Pengalaman kelekatan yang tidak aman memiliki resiko munculnya masalah kesehatan mental dan tingkat emosional yang tinggi pada anak dan dewasa (Overbeek et al., 2005). Kelekatan yang rendah dengan orang tua dan teman cenderung menghasilkan perilaku yang negatif seperti kenakalan (Hoeve et al., 2012). Perilaku negatif lainnya seperti perilaku agresif, impulsif, membangkang, berbohong bahkan mencuri juga merupakan tanda anak memiliki kelekatan yang tidak aman dengan orang tua (Dawson et al., 2014).

Pada masa remaja, figur lekat dapat beralih pada figur lain selain pengasuh, seperti figur lekat teman (Hoeve et al., 2012). Kelekatan dengan teman memiliki peranan yang kuat dalam kehidupan remaja seperti dukungan dan kepedulian dari teman akan meningkatkan keberanian remaja dalam menghadapi dunia yang lebih baik, namun jika kelekatan terbentuk dengan teman yang nakal, remaja justru cenderung terlibat dalam perilaku yang nakal (Daigle et al., 2007). Hal ini juga sesuai dengan penelitian Icli \& Coban (2012) remaja yang dilaporkan melakukan kejahatan memiliki teman baik seorang kriminal. Freeman \& Brown (2001) juga menyatakan bahwa pada usia remaja figur kelekatan utama dapat berubah dari orang tua menjadi kepada teman. Proses pelepasan orang tua sebagai figur kelekatan utama berawal saat awal remaja dan berakhir saat lulus sekolah menengah atas. Teman memiliki pengaruh yang mendalam bagi remaja, terutama saat hubungan keduanya semakin dekat. Remaja menghabiskan banyak waktu bersama dengan anggota kelompok teman sebaya di luar rumah. Keadaan remaja yang sering berada di luar rumah meningkatkan pengaruh teman terhadap sikap remaja, cara berbicara, ketertarikan, penampilan, dan perilaku yang tidak ada di keluarga.

Menurut Bergin \& Bergin (2009), anak yang memiliki kelekatan yang aman baik dengan orang tua ataupun teman cenderung memiliki self esteem yang tinggi, kompetensi sosial yang tinggi, dan peringkat yang tinggi. Penelitian Husnina \& Nugraha (2016) mengungkapkan bahwa self esteem andikpas Lembaga Pembinaan Khusus Anak Kelas II Bandung tergolong cukup baik, namun terdapat 26,56 persen andikpas yang memiliki self-esteem yang rendah. Temuan tersebut mengindikasikan adanya beragam faktor yang membuat andikpas mempunyai self-esteem yang masih rendah yang juga mengindikasikan tingkat kenakalan yang terjadi. Salah satu faktor yang menarik untuk dikaji lebih lanjut adalah faktor pengasuhan dan juga hubungan dengan teman sebaya. Oleh karenanya, 
penelitian ini ingin menganalisis lebih lanjut kelekatan remaja dengan orang tua dan teman sebaya serta kaitannya dengan tingkat kenakalan remaja yang menjadi andikpas di Lembaga Pembinaan Khusus Anak Kelas II Bandung. Secara khusus, penelitian ini bertujuan untuk (1) mengidentifikasi kelekatan remaja dengan orang tua (ayah dan ibu) dan teman sebaya serta tingkat kenakalan remaja di Lembaga Pembinaan Khusus Anak Kelas II Bandung dan (2) menganalisis pengaruh karakteristik remaja, karakteristik keluarga, kelekatan remaja dengan ayah, ibu, dan teman sebaya terhadap kenakalan remaja yang menjadi andikpas di Lembaga Pembinaan Khusus Anak Kelas II Bandung.

\section{METODE}

Desain penelitian ini adalah cross-sectional study. Penelitian ini menggunakan metode retrospective, yaitu peneliti ingin menggali informasi yang sudah terjadi di masa lampau (sebelum masuk LPKA) berkaitan dengan kelekatan remaja dengan orang tua, teman sebaya, dan kenakalan remaja. Penelitian dilaksanakan di Lembaga Pembinaan Khusus Anak Kelas II Bandung. Pemilihan lokasi dilakukan secara purpossive dengan mempertimbangkan bahwa Lembaga Pembinaan Khusus Anak Kelas II Bandung memiliki jumlah anak didik lapas yang paling banyak. Penelitian dilakukan melalui tahapan persiapan, pengumpulan data, pengolahan data, analisis data, dan penulisan laporan terhitung dari bulan Februari hingga Juni 2016.

Populasi dalam penelitian ini adalah anak didik lapas (andikpas) yang berada di Lembaga Pembinaan Khusus Anak Kelas II Bandung dengan usia 15-18 tahun yang berjumlah 157 orang. Sementara itu, penarikan contoh dipilih secara probability sampling dengan teknik penarikan contoh secara simple random sampling. Jumlah contoh didapatkan dengan menggunakan rumus Slovin yaitu sebanyak 63 anak.

Data primer dalam penelitian ini dikumpulkan dengan menggunakan teknik wawancara. Data tersebut meliputi karakteristik remaja, keluarga, dan teman sebaya; kelekatan remaja dengan ibu, ayah, dan teman sebaya; serta kenakalan remaja yang menjadi andikpas. Data karakteristik remaja meliputi usia dan riwayat putus sekolah. Usia remaja dikelompokkan berdasarkan Cobb (2001); yang membagi menjadi dua kategori; yaitu remaja awal yang berusia 12 hingga 15 tahun dan remaja akhir berusia 16 hingga 18 tahun.
Sementara itu, data karakteristik keluarga meliputi besar keluarga, status pernikahan orang tua, dan jumlah aset keluarga. Besar keluarga dikelompokkan menjadi keluarga kecil ( $\leq 4$ orang), keluarga sedang (5-7 orang), dan keluarga besar ( $\geq 8$ orang). Data karakteristik teman sebaya meliputi jumlah teman dekat, keragaman usia di kelompok teman, keragaman jenis kelamin di kelompok teman, asal lingkungan teman sebaya, lama pertemanan dengan anggota kelompok, keberadaan pemimpin dalam kelompok teman, keberadaan atribut penciri kelompok, kegiatan saat bersama teman sebaya, dan lama waktu yang dihabiskan saat berkumpul.

Variabel kelekatan diukur menggunakan instrumen versi revisi dari Armsden \& Greenberg (1987) yang berjudul "Inventory Parent and Peer Attachment (IPPA)" berjumlah 75 pernyataan yang terbagi masing masing 25 pernyataan untuk kelekatan dengan ibu, kelekatan dengan ayah, dan kelekatan dengan teman sebaya. Nilai Cronbach's alpha kelekatan dengan ibu sebesar 0,747, sedangkan Cronbach's alpha kelekatan remaja dengan ayah sebesar 0,825. Adapun nilai Cronbach's alpha kelekatan remaja dengan teman sebaya sebesar 0,799. Selanjutnya kelekatan dikategorikan menjadi kelekatan aman (secure) dan tidak aman (insecure). Setiap bagian kelekatan terdiri atas 3 dimensi yaitu dimensi kepercayaan, komunikasi, dan pengasingan. Pengukuran menggunakan skala Likert yang terdiri dari selalu diberi skor 5 , sering diberi skor 4, kadang-kadang diberi skor 3 , jarang diberi skor 2 , dan tidak pernah diberi skor 1.

Sementara itu, variabel kenakalan remaja diukur dengan menggunakan instrumen Adapted Self Report Delinquency Scale (ASRDS) yang diadaptasi versi Portugis oleh Pechorro et al. (2015) dari instrumen asli yang dikembangkan oleh Carroll et al. (1996). Instrumen kenakalan remaja dalam penelitian ini memiliki nilai Cronbach's alpha sebesar 0,875 dan terdiri dari 35 pernyataan yang terbagi ke dalam 7 dimensi yaitu pencurian, kejahatan di jalan, alkohol dan obat terlarang, agresi, perusakan, kejahatan di sekolah, serta mengganggu masyarakat. Instrumen ini diukur dengan menggunakan skala Likert yang terdiri dari sering diberi skor 3, kadang-kadang diberi skor 2, dan tidak pernah diberi skor 1 .

Data dianalisis menggunakan analisis deskriptif dan inferensia. Analisis deskriptif yang digunakan meliputi frekuensi, nilai maksimum, nilai minimum, rata-rata, dan 
standar deviasi. Analisis inferensia yang dilakukan meliputi uji korelasi dan uji regresi berganda. Sebelum dilakukan analisis data, data diolah dengan mengubahnya ke dalam bentuk indeks (0,0-100,0). Jawaban kemudian dikompositkan dengan mentransformasi nilai atau skor yang telah didapatkan menjadi skor indeks. Skor indeks diperoleh dengan cara mengurangi skor responden dengan skor minimal, kemudian dibagi dengan hasil pengurangan dari skor maksimal dengan skor minimal, dan hasil pembagian tersebut kemudian dikalikan dengan 100. Pada variabel kenakalan remaja skor indeks yang dicapai tersebut, dikategorikan dengan menggunakan cut-off point skor indeks, yaitu rendah $(0,0$ $38,8)$ dan tinggi $(38,8-100,0)$.

Pada variabel kelekatan, kelekatan dikategorikan menjadi kelekatan aman (high security/secure) dan kelekatan tidak aman (low security/insecure). Kategori high security (HS) atau secure ditunjukkan dengan nilai dimensi kepercayaan dan dimensi komunikasi minimal berada pada kategori sedang dan nilai pengasingan tidak tinggi. Apabila nilai dimensi kepercayaan sedang dan nilai dimensi pengasingan juga sedang, maka bukan termasuk ke dalam kelompok high security (HS). Sementara itu, low security (LS) atau insecure ditentukan dengan nilai dimensi kepercayaan dan dimensi komunikasi rendah, sedangkan nilai dimensi pengasingan sedang atau tinggi. Apabila nilai dimensi pengasingan tidak lebih tinggi daripada nilai dimensi kepercayaan dan dimensi komunikasi, maka bukan termasuk kedalam kelompok low security (LS).

Data dianalisis dengan analisis deksriptif dan inferensia. Analisis deskriptif digunakan untuk mencari persentase, nilai rataan, standar deviasi, nilai minimun, dan nilai maksimum. Analisis inferensia yang digunakan adalah uji regresi linear berganda. Uji regresi linear berganda bertujuan untuk menjelaskan lebih rinci mengenai pengaruh kelekatan remaja dengan ibu, ayah, dan teman sebaya terhadap tingkat kenakalan remaja yang menjadi andikpas di LPKA Kelas II Bandung.

\section{HASIL}

\section{Karakteristik Keluarga}

Hasil uji deskriptif menunjukkan bahwa separuh remaja $(52,4 \%)$ berada pada kategori keluarga sedang dengan jumlah anggota keluarga 5 sampai dengan 7 orang. Berdasarkan tipe keluarga, remaja yang memiliki orang tua dengan status menikah adalah sebanyak 79,4 persen, sedangkan remaja yang memiliki orang tua dengan status bercerai 9,5 persen. Sementara itu, remaja dengan orang tua yang memiliki status menikah lagi sebesar 11,1 persen. Berdasarkan jenis pekerjaan, terdapat lebih dari satu per empat ayah remaja $(28,6 \%)$ memiliki pekerjaan sebagai buruh. Sebagian besar remaja $(76,2 \%)$ mengungkapkan bahwa ibu remaja adalah ibu rumah tangga.

Kepemilikan aset yang dimiliki keluarga terdiri dari kepemilikan rumah, kendaraan, elektronik, dan pertanian. Hasil penelitian menunjukkan bahwa lebih dari separuh keluarga remaja $(69,8 \%)$ memiliki rumah dengan kepemilikan sendiri. Selain itu, hampir seluruh keluarga remaja $(92,1 \%)$ memiliki kendaraan bermotor dan hanya sebagian kecil keluarga remaja $(19,0 \%)$ yang memiliki mobil. Pada kepemilikan aset elektronik, seluruh keluarga remaja $(100,0 \%)$ memiliki barang elektronik yaitu televisi dan hanya sebagian kecil $(7,9 \%)$ keluarga remaja yang memiliki AC. Pada kepemilikan lahan pertanian, terdapat 25,4 persen keluarga remaja memiliki lahan pertanian sawah.

\section{Karakteristik Remaja}

Seluruh remaja yang menjadi remaja dalam penelitian berjenis kelamin laki-laki. Usia remaja berkisar antara 15 sampai 18 tahun dengan rata-rata usia 17 tahun. Rata-rata lama hukuman remaja 42 bulan atau sekitar 3,5 tahun dengan lama hukuman paling rendah 7 bulan dan hukuman paling tinggi 120 bulan. Sebagian besar remaja telah memiliki pekerjaan, hanya sebesar 33,8 persen remaja yang merupakan pelajar.

Setelah masuk ke LPKA II Bandung, remaja yang putus sekolah kembali mendapatkan pendidikan seperti Kejar Paket $A$ untuk tingkat $\mathrm{SD}$, Kejar Paket $\mathrm{B}$ untuk tingkat SMP, dan Kejar Paket C untuk tingkat SMA. Sementara itu, remaja yang tidak putus sekolah mendapatkan pendidikan sesuai dengan tingkat pendidikan formal sebelum memasuki LKPA II Bandung.

\section{Karakteristik Teman Sebaya}

Berdasarkan hasil penelitian tentang jumlah anggota teman sebaya menunjukkan bahwa sebanyak 71,4 persen remaja memiliki teman sebaya dengan jumlah anggota lebih dari 8 orang. Hasil penelitian juga menemukan bahwa kurang dari satu per empat $(22,3 \%)$ 
teman sebaya remaja memiliki anggota dengan usia yang sama. Selain itu, hasil penelitian juga menemukan bahwa sekitar tujuh dari sepuluh remaja $(76,2 \%)$ memiliki kelompok teman sebaya dengan anggota yang usianya lebih tua. Berdasarkan jenis kelamin, remaja memiliki kelompok teman sebaya yang beranggotakan dari jenis kelamin yang berbeda sebanyak 58,7 persen. Jenis kelamin yang berbeda dikelompok teman sebaya dapat mendorong adanya aktivitas seksual mengingat pada usia ini remaja mengalami perubahan fisik, emosi, dan dorongan seksual.

Hasil penelitian menemukan bahwa kelompok teman sebaya remaja yang mempunyai pemimpin dalam kelompoknya sebanyak 33,3 persen. Biasanya, usia pemimpin kelompok lebih tua dibandingkan dengan anggota kelompoknya. Pada penelitian ini, sebagian besar remaja $(77,8 \%)$ memiliki kelompok teman yang anggotanya berusia lebih tua dibandingkan remaja. Hal ini menunjukkan bahwa dalam kelompok teman sebaya terdapat anggota yang lebih tua dan lebih dihormati. Teman yang lebih tua cenderung lebih mendominasi dan menjadi pemimpin dalam kelompok pertemanan. Adapun kelompok teman sebaya dengan kategori usia yang sama sebesar 22,2 persen. Kelompok ini biasanya dipimpin oleh remaja yang dianggap tua dalam kelompoknya.

Berdasarkan waktu yang dihabiskan remaja dengan kelompok teman sebayanya, ditemukan bahwa sekitar tujuh dari sepuluh remaja $(71,4 \%)$ menyatakan telah mengenal anggota kelompok teman sebayanya lebih dari 3 tahun. Lama pertemanan menunjukkan kualitas pertemanan yang terbangun antara remaja dan kelompok teman sebayanya. Selain itu, lebih dari tiga per empat remaja $(76,2 \%)$ memiliki frekuensi berkumpul dengan dengan kelompok teman sebayanya lebih dari empat kali dalam satu minggu. Setiap harinya dua dari tiga remaja $(66,7 \%)$ dapat menghabiskan waktu lebih dari 6 jam untuk berkumpul dengan teman sebayanya dengan kegiatan mulai dari mengobrol, nongkrong, minum kopi, touring sepeda motor, bahkan tawuran. Pada penelitian ini remaja terpengaruh untuk melakukan berbagai kebiasaan yang sama dengan teman sebayanya seperti merokok dan minumminuman beralkohol.

Suatu kelompok pertemanan biasanya memiliki atribut yang sama sebagai ciri-ciri kelompok mereka. Namun terdapat juga kelompok yang tidak memiliki atribut khusus yang mencirikan keanggotaanya. Penelitian ini menemukan bahwa sebanyak 79,4 persen remaja menyatakan memiliki atribut khusus sebagai ciri keanggotaan dalam kelompok mereka. Persentase terbesar baju $(31,7 \%)$ merupakan atribut kelompok teman sebayanya. Atribut lainnya terdiri atas jaket $(28,6 \%)$, gelang $(4,8 \%)$, slayaer $(3,2 \%)$, topi $(1,6 \%)$, bahkan senjata tajam seperti samurai $(1,6 \%)$. Senjata tajam tersebut biasa digunakan untuk berjaga-jaga apabila bertemu dengan kelompok teman sebaya lainnya yang dianggap sebagai musuh.

Penelitian ini juga menemukan bahwa sebesar 30,2 persen remaja mengungkapkan kegiatan yang dilakukan bersama kelompok teman sebayanya saat berkumpul adalah nongkrong hingga larut malam sampai minum-minuman beralkohol bersama-sama. Hal tersebut menunjukkan bahwa karakteristik dari teman sebaya remaja cenderung memiliki perilaku yang kurang baik. Temuan lainnya adalah setengah remaja $(52,4 \%)$ memiliki teman sebaya yang berasal dari lingkungan rumahnya, bahkan terdapat kombinasi antara lingkungan rumah dengan jalanan sehingga dapat disimpulkan bahwa remaja berada di lingkungan tempat tinggal yang kurang baik.

\section{Kelekatan Remaja dengan Ibu, Ayah, dan Teman Sebaya}

Berdasarkan hasil analisis yag tersaji pada Tabel 1, terlihat bahwa dua dimensi kelekatan ayah dengan remaja yaitu dimensi kepercayaan (rata-rata indeks $=65,24$ ) dan dimensi komunikasi (rata-rata indeks $=54,81$ ) memiliki nilai yang lebih rendah dibandingkan kelekatan remaja dengan ibu dan teman sebaya. Dimensi kepercayaan yang rendah menunjukkan bahwa remaja belum merasa aman bila di dekat ayahnya sehingga ayah belum menjadi figur yang membantu setiap masalah dan dapat memenuhi kebutuhan remaja.

Tabel 1 Rata-rata dan standar deviasi indeks kelekatan remaja dengan ibu, ayah, dan teman sebaya

\begin{tabular}{lccc}
\hline $\begin{array}{c}\text { Dimensi } \\
\text { Kelekatan }\end{array}$ & Ibu & Ayah & $\begin{array}{c}\text { Teman } \\
\text { Sebaya }\end{array}$ \\
\hline $\begin{array}{l}\text { Keperca- } \\
\text { yaan }\end{array}$ & $74,52 \pm 10,68$ & $65,24 \pm 14,41$ & $71,47 \pm 15,58$ \\
Komunika- & $63,14 \pm 13,82$ & $54,81 \pm 16,67$ & $65,72 \pm 14,99$ \\
si & & & \\
Pengasing- & $30,29 \pm 16,38$ & $31,15 \pm 16,05$ & $37,07 \pm 13,94$ \\
an & & & \\
Kelekatan & $69,27 \pm 10,30$ & $62,14 \pm 12,98$ & $67,35 \pm 11,18$ \\
total
\end{tabular}


Dimensi komunikasi yang rendah dengan ayah juga menunjukkan bahwa remaja tidak bercerita tentang masalahnya pada ayah dan lebih memilih berdiam diri. Selanjutnya secara umum, rata-rata kelekatan total remaja dengan ayah juga lebih rendah dibandingkan dengan kelekatan remaja dengan ibu dan teman sebaya. Hasil penelitian juga menunjukkan pada dimensi pengasingan, kelekatan remaja dengan teman sebaya memiliki nilai indeks rata-rata yang paling tinggi dibandingkan kelekatan remaja dengan ibu maupun ayah. Temuan ini mengindikasikan bahwa remaja yang menjadi remaja cenderung lebih banyak menghindar atau ditolak dari teman sebayanya.

Hasil analisis yang ditersaji pada Tabel 2 menunjukkan proporsi terbesar kategori kelekatan remaja dengan ibu, ayah, maupun teman sebaya berada pada kelekatan tidak aman. Kategori kelekatan tidak aman yang memiliki proporsi paling besar berada pada figur ayah (87,3\%). Teman sebaya memiliki proporsi terbesar pada kategori kelekatan aman dibandingkan dengan figur ibu dan ayah.

\section{Kenakalan Remaja}

Kenakalan remaja digambarkan sebagai kegagalan untuk mengembangkan kontrol diri yang cukup dalam bertingkah laku. Kenakalan remaja (juvenile delinquency) mengacu pada rentang yang luas, mulai dari tingkah laku yang tidak dapat diterima secara sosial hingga tindak kriminal (Santrock, 2003). Hasil penelitian menemukan bahwa terdapat beragam kasus yang menjadi penyebab remaja masuk kedalam Lembaga Pembinaan Khusus Anak Kelas II Bandung. Hasil penelitian menunjukkan bahwa terdapat 47,6 persen remaja yang memiliki angka kenakalan yang rendah, sedangkan remaja dengan angka kenakalan yang tinggi terdapat sebanyak 52,4 persen. Rata-rata tingkat kenakalan remaja ada pada angka 38,8 persen.

Tabel 2 Perbandingan sebaran kategori kelekatan remaja dengan ibu, ayah, dan teman sebaya

\begin{tabular}{lcccccc}
\hline \multirow{2}{*}{$\begin{array}{c}\text { Kategori } \\
\text { kelekatan }\end{array}$} & \multicolumn{2}{c}{$\mathrm{lbu}$} & \multicolumn{2}{c}{ Ayah } & \multicolumn{2}{c}{$\begin{array}{c}\text { Teman } \\
\text { Sebaya }\end{array}$} \\
\cline { 2 - 7 } & $\mathrm{n}$ & $\%$ & $\mathrm{n}$ & $\%$ & $\mathrm{n}$ & $\%$ \\
\hline Aman & 12 & 19,0 & 8 & 12,7 & 13 & 20,6 \\
$\begin{array}{l}\text { Tidak } \\
\text { aman }\end{array}$ & 51 & 81,0 & 55 & 87,3 & 50 & 79,4 \\
\hline Total & 63 & 100,0 & 63 & 100,0 & 63 & 100,0 \\
\hline
\end{tabular}

Tabel 3 menunjukkan berbagai dimensi kenakalan remaja, diantaranya dimensi pencurian atau perampokan, kejahatan di jalan, kejahatan berhubungan dengan alkohol dan obat terlarang, agresi, perusakan, kejahatan di sekolah, dan kejahatan mengganggu masyarakat. Dimensi kejahatan yang berhubungan dengan alkohol dan obatobatan terlarang memiliki nilai rata-rata yang paling tinggi. Hal ini menunjukkan bahwa sebagian besar remaja melakukan kejahatan yang berhubungan dengan alkohol dan obatobatan terlarang seperti membeli minuman beralkohol, meminum minuman beralkohol, mengendarai motor dalam keadaan mabuk, dan merokok.

Sementara itu, pada Tabel 4 disajikan bentuk perilaku nakal dengan nilai rataan jawaban tertinggi $(\geq 2)$ yang ditemukan dalam penelitian ini. Bentuk perilaku nakal dengan nilai rataan jawaban tertinggi yaitu membeli minuman beralkohol, memimum minuman beralkohol, dan merokok. Jawaban dengan nilai rataan tertinggi menunjukkan bahwa remaja melakukan perilaku tersebut dengan intensitas kadang-kadang sampai sering. Kejahatan yang berhubungan dengan alkohol dan obat-obatan terlarang adalah bentuk kenakalan remaja yang paling banyak dilakukan oleh remaja. Selain bentuk kenakalan ini banyak dilakukan, remaja juga dapat melakukannya dengan intensitas kadang-kadang sampai sering. Hal ini menunjukkan bahwa alkohol telah menjadi masalah kesehatan utama pada remaja. Alasan remaja meminum minuman beralkohol adalah untuk dapat menghilangkan stres dan depresi atas permasalahan yang mereka hadapi.

Tabel 3 Nilai minimal, maksimal, rata-rata, dan standar deviasi dimensi kenakalan remaja (indeks)

\begin{tabular}{lcc}
\hline \multicolumn{1}{c}{$\begin{array}{c}\text { Dimensi } \\
\text { kenakalan } \\
\text { remaja }\end{array}$} & Min-max & Rata-rata $\pm S D$ \\
\hline $\begin{array}{l}\text { Pencurian atau } \\
\text { perampokan }\end{array}$ & $0,0-70,0$ & $22,54 \pm 20,31$ \\
$\begin{array}{l}\text { Kejahatan di } \\
\text { jalan }\end{array}$ & $0,0-83,0$ & $41,14 \pm 21,42$ \\
$\begin{array}{l}\text { Alkohol dan } \\
\text { obat terlarang }\end{array}$ & $9,0-100,0$ & $63,23 \pm 24,44$ \\
$\begin{array}{l}\text { Agresi } \\
\text { Perusakan }\end{array}$ & $0,0-80,0$ & $36,51 \pm 23,29$ \\
$\begin{array}{l}\text { Kenakalan di } \\
\text { sekolah }\end{array}$ & $0,0-80,0$ & $21,27 \pm 16,64$ \\
$\begin{array}{l}\text { Mengganggu } \\
\text { masyarakat }\end{array}$ & $0,0-100,0$ & $48,15 \pm 24,88$ \\
\hline
\end{tabular}


Tabel 4 Sebaran perilaku kenakalan dengan nilai rataan jawaban tertinggi

\begin{tabular}{lcrlr}
\hline \multirow{2}{*}{ Kenakalan remaja } & \multicolumn{2}{c}{ Frekuensi } & \multirow{2}{*}{ Rataan jawaban } \\
\cline { 2 - 3 } & $\mathrm{n}$ & \multicolumn{2}{c}{$\%$} & 2,3 \\
\hline Kebut-kebutan di jalan & 53 & 84,1 & 2,0 \\
Terlibat balapan motor & 40 & 63,4 & 2,6 \\
Membeli minuman beralkohol & 60 & 95,2 & 2,6 \\
Meminum minuman beralkohol & 60 & 95,2 & 2,8 \\
Merokok & 60 & 95,2 & 2,1 \\
Mengendarai motor dalam keadaan mabuk & 48 & 76,2 & 2,1 \\
Tawuran antar kelompok & 49 & 77,8 & 2,1 \\
Memukul orang lain & 55 & 87,3 & 2,0 \\
Menonton film porno & 53 & 84,1 & \\
\hline
\end{tabular}

\section{Faktor-faktor yang Memengaruhi Kenakalan Remaja}

Uji regresi linear berganda dilakukan untuk menganalisis pengaruh variabel bebas terhadap kenakalan remaja yang menjadi remaja. Variabel bebas yang diuji adalah usia remaja, besar keluarga, jumlah aset keluarga, kelekatan dengan ayah, kelekatan dengan ibu, dan kelekatan dengan teman sebaya. Sementara itu, kenakalan remaja merupakan variabel terikat dalam penelitian ini. Hasil dari uji regresi linear berganda menunjukkan nilai adjusted $\mathrm{R}^{2}$ sebesar 0,117 . Hal ini berarti sebesar 11,7 persen kenakalan remaja dipengaruhi oleh variabel bebas yang diuji, sedangkan sisanya dipengaruhi oleh variabel bebas lain di luar penelitian.

Hasil uji regresi linear berganda menunjukkan bahwa kelekatan remaja dengan ayah dan kelekatan remaja dengan teman sebaya memengaruhi kenakalan remaja. Kelekatan remaja dengan ayah $(B=-0,358 ; \quad p=0,05)$ memiliki pengaruh negatif signifikan terhadap kenakalan remaja. Hal ini berarti penambahan satu skor variabel kelekatan remaja dengan ayah akan menurunkan tingkat kenakalan remaja sebesar 0,358 poin dan sebaliknya. Hasil berbeda ditemukan pada kelekatan remaja dengan teman sebaya yang berpengaruh positif signifikan terhadap kenakalan remaja $(B=0,397 ; p=0,05)$. Hal ini berarti penambahan satu skor variabel kelekatan remaja dengan teman sebaya akan meningkatkan tingkat kenakalan remaja sebesar 0,397 poin dan sebaliknya (Tabel 5). Temuan ini mengindikasikan bahwa kelekatan yang tinggi yang terbangun antara remaja dengan teman sebayanya merupakan faktor resiko munculnya kenakalan remaja. Hal ini dapat terjadi mengingat karakteristik kelompok teman sebaya yang paling sering berinteraksi dengan remaja adalah kelompok pertemanan yang tidak sehat dan cenderung menjadi teman dalam melakukan berbagai perilaku negatif.

\section{PEMBAHASAN}

Kelekatan adalah ikatan kasih sayang yang kokoh atau kuat (Armsden \& Greenberg, 1987). Kelekatan terbentuk pada individu lain secara spesifik seperti individu yang hangat, sensitif, dan responsif (Ainsworth, 1969). Ibu merupakan figur kelekatan utama karena menjadi tempat bagi anak untuk mengembangkan ikatan emosi di sepanjang hidupnya, seperti perasaan aman yang dirasakan anak saat sedang takut atau sakit.

Tabel 5 Faktor-faktor yang memengaruhi kenakalan remaja

\begin{tabular}{|c|c|c|c|}
\hline Variabel & Tidak terstandarisasi (B) & Terstandarisasi $(\beta)$ & Sig. \\
\hline Konstanta & 48,181 & & 0,023 \\
\hline Usia ( $0=$ remaja awal; $1=$ remaja akhir) & $-6,127$ & $-0,073$ & 0,561 \\
\hline Besar keluarga (jumlah) & 0,250 & 0,028 & 0,824 \\
\hline Total jumlah aset (indeks) & 0,271 & 0,215 & 0,088 \\
\hline Kelekatan dengan ibu (indeks) & $-0,309$ & $-0,214$ & 0,158 \\
\hline Kelekatan dengan ayah (indeks) & $-0,358$ & $-0,312$ & $0,048^{*}$ \\
\hline Kelekatan dengan teman sebaya (indeks) & 0,397 & 0,298 & $0,049^{*}$ \\
\hline $\mathrm{R}^{2}$ & & 0,202 & \\
\hline $\mathrm{R}^{2}$ Adjusted & & 0,117 & \\
\hline $\mathrm{F}$ & & 2,365 & \\
\hline Sig. & & 0,042 & \\
\hline
\end{tabular}

Keterangan: *nyata pada $p<0,05$ 
Figur kelekatan dapat berkembang pada orang yang dikenal baik oleh figur kelekatan utama dan sering bertemu seperti ayah, nenek, teman, tetangga, dan penjaga anak (Bowlby, 2007). Saat anak semakin beranjak dewasa, figur kelekatan lain akan semakin penting seperti teman dekat dan pasangan. Armsden \& Greenberg (1987) mengkategorikan kelekatan menjadi kelekatan aman dan kelekatan tidak aman berdasarkan tiga dimensi yaitu kepercayaan, komunikasi, dan pengasingan.

Hasil penelitian menemukan bahwa sebagian besar remaja memiliki kelekatan yang tidak aman dengan ibu, ayah, maupun teman sebayanya. Pada kategori kelekatan aman, figur teman sebaya memiliki proporsi nilai paling besar diantara figur lainnya. Kelekatan dengan skor dimensi kepercayaan dan komunikasi yang paling rendah adalah kelekatan remaja dengan ayah. Kelekatan yang tidak aman menunjukkan bahwa remaja dalam penelitian ini belum mendapatkan kepercayaan pada masing-masing figur lekat untuk dapat memahami dengan tepat kebutuhannya dan memberikan dukungan ketika dibutuhkan. Hasil yang berbeda ditemukan pada penelitian tentang kelekatan yang dilakukan selain di Lembaga Pembinaan Khusus Anak (LPKA), seperti pada penelitian Krisnatuti \& Putri (2012) yang menemukan bahwa sebagian besar remaja memiliki kelekatan yang aman dengan ayahnya. Remaja perempuan dengan kelekatan aman sebesar 70,0 persen dan kelekatan tidak aman sebesar 30,0 persen, sedangkan pada remaja laki-laki kelekatan aman sebesar 86,7 persen dan kelekatan tidak aman sebesar 13,3 persen (Krisnatuti \& Putri, 2012).

Menurut teori perkembangan Erik Erikson (Santrock, 2003), masa remaja adalah masa pencarian identitas yang berada di tahap identitas versus kebingungan identitas. Erikson berpendapat bahwa kenakalan dihubungkan dengan kemampuan remaja mengatasi krisis kebingungan identitas secara positif sehingga bagi Erikson kenakalan merupakan suatu upaya untuk membentuk suatu identitas, meskipun identitas tersebut negatif (Santrock, 2003).

Hasil penelitian menunjukkan bahwa sebanyak 52,4 persen remaja di Lembaga Pembinaan Khusus Anak Kelas II Bandung berada pada kategori kenakalan tinggi. Penilaian dimensi pada variabel kenakalan menunjukkan bahwa dimensi kejahatan yang berkaitan dengan alkohol dan obat-obatan terlarang memiliki nilai rataan yang paling tinggi. Berdasarkan hasil wawancara, remaja mengonsumsi alkohol dan obat-obatan terlarang agar dapat mengurangi kecemasan atau keluar dari suatu masalah. Masalah yang dialami remaja diakibatkan oleh keluarga, lingkungan pertemanan, musuh, dan lingkungan pekerjaan. Menurut Van der Vorst et al. (2006), konsumsi alkohol di usia remaja diakibatkan oleh pengawasan orang tua yang rendah, semakin rendah pengawasan orang tua terhadap anak akan meningkatkan konsumsi alkohol pada anak.

Penelitian lain juga menegaskan bahwa hubungan dengan teman memainkan peranan penting dalam pengaturan dalam diri remaja (Mota \& Matos, 2013). Dalam hubungan dengan teman, lama pertemanan dapat menunjukkan kepercayaan remaja dengan temannya satu sama lain. Kepercayaan ini menjadi salah satu dimensi penting dari kualitas pertemanan. Menurut Mota \& Matos (2013), kualitas hubungan dengan figur teman berkontribusi dalam perkembangan dasar aman remaja, terutama bagi remaja tanpa dukungan keluarga. Adapun keadaan remaja dalam penelitian ini mempunyai hubungan pertemanan dengan teman yang yang beresiko untuk bersama-sama melakukan halhal negatif. Pada penelitian ini remaja terpengaruh untuk melakukan berbagai kebiasaan negatif yang sama dengan teman sebayanya seperti merokok, minum-minuman beralkohol, dan menggunakan obat-obatan terlarang. Menurut Vitaro et al. (2002), menghabiskan waktu bersama teman yang nakal akan mendorong remaja untuk melakukan segala perilaku yang dilakukan temannya.

Kelekatan dengan teman sebaya diperantarai oleh kelekatan orang tua dengan anak sehingga anak yang memiliki kelekatan aman dengan orang tua dapat membentuk kelekatan yang aman juga pada teman sebayanya (Ma \& Huebner, 2008). Remaja yang memiliki kelekatan yang aman atau kelekatan yang tinggi dengan orang tuanya juga cenderung kurang terlibat dalam perilaku nakal dan sebaliknya (Choon et al., 2013). Adapun penelitian Williams \& Kelly (2005) yang menemukan bahwa keterlibatan dan kelekatan orang tua baik ayah maupun ibu secara signifikan dapat menjelaskan perilaku negatif remaja seperti berdebat, berkelahi, impulsif, dan hiperaktif pada laki-laki. Ketika orang tua tidak memberikan ikatan yang kuat pada anak dan tidak mengajarinya nilai-nilai yang diterima masyarakat, anak-anak cenderung mengalami kesulitan saat dimasyarakat. Kesulitan ini mendorong penolakan dari teman dan 
membuat mereka berhubungan dengan teman yang menyimpang (Clarson, 2012). Berdasarkan penelitian Elgar et al. (2003), teman yang menyimpang (nakal) menjadi faktor perantara antara kelekatan tidak aman dengan perilaku penggunaan obat terlarang. Kelekatan remaja dengan orang tua dapat membuat orang tua mengetahui setiap aktivitas anak dan pergaulan anak sehingga orang tua mengetahui dengan siapa anak bergaul serta dapat mengontrol dan mengawasi anak untuk tidak bergaul dengan teman yang nakal.

Hasil uji pengaruh menunjukkan bahwa kelekatan dengan ayah memiliki pengaruh negatif signifikan terhadap kenakalan remaja. Hal ini menunjukkan bahwa kelekatan tidak aman dengan ayah memberikan pengaruh pada tingkat kenakalan remaja. Menurut Hoeve et al. (2012), kekuatan pengaruh antara kenakalan remaja dan kelekatan dengan orang tua ditemukan lebih besar pada orang tua dan anak dengan jenis kelamin yang sama. Seluruh remaja pada penelitian ini berjenis kelamin laki-laki sehingga ayah berperan penting dalam perkembangan peran gender seperti sifat maskulin yang dimiliki oleh lakilaki. Anak cenderung mengikuti perilaku orang tua dengan jenis kelamin yang sama. Berdasarkan teori pembelajaran sosial yang diungkapkan oleh Albert Bandura, perilaku nakal adalah hasil dari pembelajaran atas lingkungannya seperti anak meniru tingkah laku ayah yang agresif, impulsif, dan bahkan menyimpang (Berndt, 2002).

Hasil penelitian Marcus \& Betze (1996) juga menemukan bahwa remaja laki-laki yang berperilaku antisosial berhubungan dengan kualitas kelekatan dengan ayah yang rendah. Hal yang sama juga diungkapkan oleh Verschueren \& Marcoen (1999) yang mengungkapkan bahwa anak yang memiliki kelekatan yang aman dengan ayahnya lebih sedikit terlibat dalam perilaku bermasalah. Hal ini sesuai dengan hasil penelitian ini yang mana remaja seluruhnya berjenis kelamin lakilaki sehingga kelekatan terhadap ayah memiliki pengaruh yang lebih kuat terhadap kenakalan remaja. Hal ini menunjukkan bahwa kelekatan dengan ayah lebih penting bagi lakilaki apabila diperhatikan dari segi perkembangan perilaku menyimpang seperti kenakalan remaja.

Selain kelekatan dengan ayah, kelekatan dengan teman sebaya juga memiliki pengaruh terhadap kenakalan remaja. Hasil menunjukkan bahwa kelekatan dengan teman sebaya berpengaruh positif terhadap kenakalan remaja. Hal ini berbeda dengan kelekatan dengan ayah yang memiliki pengaruh negatif signifikan. Berdasarkan teori pembelajaran sosial, dorongan untuk meniru perilaku teman akan semakin besar saat teman memiliki hubungan yang lebih positif dengan remaja. Hasil penelitian menemukan bahwa karakteristik teman sebaya remaja memiliki kegiatan yang kurang positif saat berkumpul seperti nongkrong, minumminuman beralkohol, touring, bahkan tawuran. Remaja yang lekat dengan teman sebayanya justru lebih banyak terlibat dalam perilaku negatif karena mereka meniru perilaku teman sebayanya. Remaja dengan kelekatan tidak aman lebih rentan dari pengaruh teman yang negatif (McElhaney et al., 2006). Hasil penelitian Menurut Vries et al. (2016) teman yang menyimpang memiliki hubungan dengan perilaku kenakalan pada remaja.

Penelitian ini menunjukkan bahwa kenakalan remaja dipengaruhi sangat kuat oleh kelekatan remaja dengan teman sebaya dan selanjutnya dipengaruhi oleh kelekatan remaja dengan ayah. Penelitian menemukan 11,7 persen variabel bebas yang diduga memengaruhi tingkat kenakalan remaja. Choon et al. (2013) melakukan penelitian terhadap 240 siswa lakilaki dan 240 siswa perempuan pada empat sekolah yang ada di Selangor. Hasil penelitian tersebut menunjukkan bahwa faktor penentu kenakalan remaja adalah jenis kelamin, kelekatan dengan teman, kelekatan dengan ibu, dan kelekatan dengan ayah dengan adjusted $R$ square sebesar 0,139 . Adapun penelitian Nisar et al. (2015) yang dilakukan di Central Jail Peshawar Pakistan menemukan bahwa sebagian besar responden menghabiskan waktu bersama teman dan menyalahkan mereka atas kepribadiannya yang negatif. Hasil lainnya yaitu sebagian besar dari responden telah bekerja dan ketidakpuasan terhadap pendapatan, ekonomi lemah, dan pendidikan yang rendah mengakibatkan mereka berperilaku nakal.

Penelitian ini memiliki keterbatasan yaitu tidak dilakukannya wawancara mendalam dengan orang tua remaja yang menjadi remaja untuk dapat menelaah lebih lanjut penyebab terbentuknya kelekatan secure maupun insecure. Berdasarkan hal tersebut, diperlukan penelitian lanjutan yang mengukur kelekatan dengan instrumen lain seperti AAI (Adult Attachment Interview) dan kelekatan diukur bukan hanya atas perspektif anak remaja saja, melainkan juga berdasarkan perspektif orang tua. 


\section{SIMPULAN DAN SARAN}

Hasil penelitian menunjukkan bahwa proporsi terbesar kelekatan remaja dengan ibu, ayah, maupun teman sebaya berada pada kategori kelekatan tidak aman. Kenakalan remaja yang menjadi andikpas di LPKA Kelas II Bandung memiliki proporsi terbesar berada pada tingkat kenakalan remaja tinggi. Dimensi kenakalan dengan nilai rataan tertinggi adalah kenakalan yang berhubungan dengan alkohol dan obat terlarang. Hasil uji pengaruh menunjukkan bahwa kelekatan terhadap ayah memiliki pengaruh negatif signifikan terhadap kenakalan remaja. Hal ini menunjukkan bahwa penurunan tingkat kelekatan remaja dengan ayah akan meningkatkan keterlibatan remaja dalam perilaku kenakalan. Selain itu, kelekatan remaja dengan teman sebaya memiliki pengaruh positif terhadap kenakalan remaja. Hal ini berarti peningkatan kelekatan remaja yang menjadi andikpas dengan kelompok teman sebayanya akan meningkatkan perilaku nakal pada remaja, mengingat lingkungan pertemanan remaja andikpas dalam penelitian ini juga cenderung merupakan teman-teman yang nakal.

Berdasarkan penelitian yang dilakukan, sebagian besar remaja telah memiliki pekerjaan sebelum remaja masuk di LPKA II Bandung, padahal usia masih muda dan masih membutuhkan bimbingan orang tua. Temuan ini mengindikasikan bahwa hendaknya orang tua dapat memberikan pengasuhan yang optimal dan menanamkan nilai moral yang dianut masyarakat. Keterlibatan ayah dalam pengasuhan dan kelekatan berperan penting dalam pembentukan perilaku anak sehingga hendaknya ayah dapat melakukan beberapa hal dalam mendukung terbentuknya kelekatan yang aman dengan remaja, seperti meningkatkan keterlibatan ayah dalam kehidupan anak remajanya. Beberapa kegiatan yang dapat meningkatkan keterlibatan ayah diantaranya adalah berkomitmen dengan waktu dalam hal pengasuhan, memberikan kehangatan dibandingkan menolak atau memusuhi, menganalisis keadaan remaja, mendukung kemandirian remaja, dan disiplin yang efektif. Sementara itu, bagi LPKA Kelas II Bandung, hasil penelitian ini menunjukkan bahwa diperlukannya program yang mendorong keluarga untuk menerapkan pengasuhan yang baik dan pengawasan yang efektif agar remaja tidak kembali terlibat dalam kenakalan remaja. Hal ini dapat dilakukan dengan menyediakan layanan konsultasi bagi orang tua andikpas yang memberikan informasi tentang pentingnya pengasuhan dan keterlibatan ayah dalam pengasuhan. Saran bagi penelitian selanjutnya, mengingat bahwa ayah terbukti merupakan figur lekat yang berpengaruh maka kajian terkait keterlibatan ayah pada anak yang menjadi andikpas perlu diperdalam. Selain itu, variabel lain seperti komunikasi antara orang tua dengan anak dan juga variabel perkembangan diri remaja perlu digali lebih lanjut untuk dapat menjelaskan fenomena kenakalan remaja saat ini.

\section{DAFTAR PUSTAKA}

Ainsworth, M. D. S. (1969). Object relations, dependency, and attachment: A theoretical review of the infant-mother relationship. Child Development, 40, 969-1025.

http://dx.doi.org/10.2307/1127008.

Armsden, G. C. \& Greenberg, M. T. (1987). The inventory of parent and peer attachment: relationship to well-being in adolescence. Journal of Youth and Adolescence, 16, 427-454.

Bergin, C. \& Bergin, D. (2009). Attachment in the classroom. Educ Psychol Rev, 21, 141-170. doi:10.1007/s10648-9104-0.

Berndt, T. J. (2002). Friendship quality and social development. American Psychological Society, 1(11), 7-10.

[BNN]. Badan Narkotika Nasional. (2014). Laporan akhir survei nasional perkembangan penyalahgunaan narkoba tahun anggaran 2014. Jakarta, ID: Badan Narkotika Nasional Republik Indonesia.

Bowlby, R. (2007). Babies and toddlers in nonparental daycare can avoid stress and anxiety if they develop a lasting secondary attachment bond with one carer who is consistently accessible to them. Attachmen and Human Development, 4, 307-319. doi:10.1080/14616730701711516.

Carroll, A., Durkin, K., Houghton, S., \& Hattie, J. (1996). An adaptation og mak's self reported delinquency scale for Western Australian adolescents. Australian Journal of Psychology, 48(1), 1-7.

Choon, L. J., Hasbullah, M., Ahmad, S., \& Ling, W. S. (2013). Parental attachment, peer attachment, and delinquency among adolescents ini Selangor, Malaysia. Asian Social Science, 9(15), 214-219. 
Clarson, A. (2012). How parents influence deviant behavior among adolescents: an analysis of their family life, their community, and their peers. Perspectives, 42-51.

Cobb, N. J. (2001). Adolescence continuity, change, and diversity fourth edition. New York, NY: Mayfield Publishing Company.

Daigle, Cullen, Wright. (2007). Gender differences in the predictors of juvenil delinquency. Youth Violence and Juvenile Justise, 3(5), 254-286.

Dawson, A. E., Allen, J. P., Martson, E. G., Hafen, C. A., \& Schad, M. M. (2014). Adolescent insecure attachment as a predictor of maladaptive coping and externalizing behaviors in emerging adulthood. Attachment and Human Development, 16, 1-17. doi:10.1080.146167734.2014.934848.

[Ditjenpas]. Direktorat Jenderal Pemasyarakatan Kementrian Hukum dan HAM. (2015a). Konferensi Lapas Anak Bandung Hasilkan Piagam Arcamanik. Diambil dari http://www.ditjenpas.go.id.

(2015b). Data narapidana anak di Lembaga Pembinaan Khusus Anak Kelas II Bandung. Sistem Database Pemasyarakatan. Diambil dari http://www.smslap.ditjenpas.go.id.

Elgar, F., Knight, J., Worrall, G. J., \& Sherman, G. (2003). Attachment characteristics and behavioral problems in rural and urban juvenile delinquents. Child Psychiatry \& Human Development, 34, 35-48. doi:10.1023/A:1025349908855.

Freeman, H. \& Brown, B. B. (2001). Primary attachment to parents and peer during adolescence: diffrence by attachment style. Journal of Youth and Adolescence, 6(30), 653-674.

Hastuti, D. (2015). Pengasuhan: teori, prinsip, dan aplikasinya di Indonesia. Bogor, ID: IPB Press.

Hoeve, M., Stams, G. J. J. M., Van der put, C. E., Dubas, J. S., Van der laan, P., \& Gerris, J. R. M. (2012). A meta-analysis of attachment to parents and delinquency. Journal Abnorm Child Psychol, 40, 771-785. doi:10.1007/s10802-011-9608-1.

Husnina, H. N. \& Nugraha, S. (2016). Hubungan social support dengan self esteem pada andikpas di Lembaga
Pembinaan Khusus Anak (LPKA) Kelas II Bandung. ISSN: 2460-6448.

Icli T. G. \& Coban S. (2012). A study on the effects of family and delinquent peers on juvenile delinquency in turkey. Advanced in Applied Sociology, 1(2), 66-72. dx.doi.org/10.4236/aasoci.2012.21009.

Kementrian Pemuda dan Olahraga. (2009). Penyajian data dan informasi kementrian pemuda dan olahraga tahun 2009. Jakarta, ID: Biro Perencanaan Kementrian Pemuda dan Olahraga.

Krisnatuti, D. \& Putri, H. A. (2012). Gaya pengasuhan orang tua, interaksi serta kelekatan ayah-remaja, dan kepuasan ayah. Jurnal IImu Keluarga dan Konsumen, 5(12), 101-109.

Ma, C. Q. \& Huebner, E. S. (2008). Attachment relationships and solescents' life satisfaction: some reltionships matter more to girls than boys. Psychology in the School, 45, 177-190. doi:10.1002/pits.20288.

Marcus, R. F. \& Betzer, P. D. (1996). Attachment and antisocial behavior in early adolescence. School Psychology Quarterly, 16, 427-444.

McElhaney, K. B., Immele, A., Smith, F. D., \& Allen, J. P. (2006). Attachment organization as moderator of the link between friendship quality and adolescent delinquency. Attachment and Human Development, 8(1), 33-46.

Mota, C. P. \& Matos, P. M. (2013). Peer attachment, coping, and self-esteem in institutionalized adolescents: the mediating reole of social skills. Eur Psychol Educ, 28, 87-100.

Nisar, M., Ullah, S., Ali, M., \& Alam, S. (2015). Juvenile delinquency: the influence of family, peer, and economic factor on juvenile delinquents. Applied Science Report, 9(1), 37-48.

Overbeek, G., Vollebegh, M., Engels, R., \& Meeus, W. (2005). Juvenile delinquency as acting out: emotional disturbance mediating the effects of parental attachment and life events. European Journal of Developmental Psychology, $1(2), 39-46$.

Pechorro, P., Vieira, R., Marôco, J., Barroso, R., \& Gonçalves, R. A. (2015). Adaptação de uma versão portuguesa da Escala de Delinquência AutoRelatada Adaptada para adolescentes. 
Revista da Associação Portuguesa de Psicologia, 29(1), 59-67.

Santrock, J. W. (2003). Adolescence: perkembangan remaja. Adelar., Saragih., penerjemah; Kristiaji., Sumiharti., editor. Adolescence, $6^{\text {th }}$ edition. Jakarta, ID: Erlangga.

Van der Vorst, H., Engels, R. C., Meeus, W., Dekovic, M., \& Vermulst, A. (2006). Parental attachment, parental control, and early development of alcohol use: A longitudinal study. Psychology of Addictive Behavior, 20, 107-116. doi:10.1037/0893-164X.20.2.107.

Verschueren, K. \& Marcoen, A. (1999). Representation of self and socioemotional competence in kindergartners: Differential and combined effects of attachment of mother to father. Child Development, 1(70), 183-201.

Vitaro, F., Brendgen, M., Tremblay, R. E. (2000). Influence of deviant friends on delinquency: searching for oderator variables. Journal of Abnormal Child Psychology, 28(4), 313-325.

Vries S. L., Hoeve M., Stams G. J., \& Asscher J. J. (2016). Adolescent-parent attachment and externalizing behavior: the mediating role of individual and social factors. Abnormal Child Psychology, 44(2), 283-294. Doi 101007/s10802-015-999-5.

Williams, S. K., Kelly, F. D. (2005). Relationships among involvement, attachment, and behaviral problems in adolescence: examining father's influence. Journal of Early Adolescence, 25(2), 168-196. 